\title{
ANALISIS STRATEGI PEMASARAN PADA PERUSAHAAN PRODUK BERAS ROSITA DI KEDIRI JAWA TIMUR
}

\author{
Anto Rujianto
}

STIE WIDYA WIWAHA

\begin{abstract}
In formulating its business strategy, the company must be clear and the selected strategy must be in accordance with the vision, mission, competence and excellence which are owned by the company. The analytical tool used to evaluate express and measure events or trends that occur outside the company is a matrix evaluation of external factors (EFE) which generates opportunities and threats, in an organization, so that it can formulate strategies to take advantage of opportunities and avoid or mitigate the impact of threats. To analyze the competition, the company carried out five forces model of competition. While the internal factor evaluation matrix (IFE) is used to evaluate, express and measure events or trends that occur inside the company such as the strengths and weaknesses of the company; then it carried out a SWOT analysis (Strength, Weakness, Opportunity, Threat) which is a series combination of external analysis and internal analysis, thus allowing known about alternatives to the strategy obtained.

Based on the analysis results which are conducted by using Michael Porter's model of five powers, it indicated that the rice supply in Kediri industry is still attractive. It is characterized by the value of interest based on the analysis of competition in the industry in the high category, the Rice Products Company "Rosita" have to constantly do a competition to gain market position with efforts to give priority to quality competition, product and price to improve service or satisfaction guarantee. Given the area known as the East Java area of a large agricultural producer; it is a great opportunity in obtaining these benefits, it must be addressed by the businesses by formulating and implementing a reliable strategy in an effort to win the competition
\end{abstract}

Keywords: external factors evaluation matrix (EFE), internal factor evaluation matrix (IFE) and SWOT analysis 


\section{Journal Competency of Business \\ 2019 Vol 3. No II}

\section{LATAR BELAKANG}

Usaha untuk mempertahankan keunggulan kompetitif membutuhkan rencana jangka panjang. Analisis SWOT yang digunakan untuk mengidentifikasikan posisi stratejik perusahaan dalam industri. Keberhasilan jangka pendek tidak lagi merupakan ukuran yang utama tentang kesuksesan, karena kesuksesan jangka panjang membutuhkan rencana dan tindakan jangka panjang yang stratejik (Widarsono, 2009). Analisis SWOT adalah identifikasi berbagai faktor secara sistematis untuk merumuskan strategi perusahaan. Analisis ini didasarkan pada logika yang dapat memaksimalkan kekuatan (Strengths) dan peluang (Opportunities), namun secara bersamaan dapat meminimalkan kelemahan (Weaknesses) dan ancaman (Threats). Proses pengambilan keputusan strategi harus menganalisis faktor-faktor strategis perusahaan (kekuatan, kelemahan, peluang, dan ancaman) dalam kondisi yang ada pada saat ini.

Pabrik Beras Rosita merupakan salah satu perusahaan yang ada di daerah Kediri yang bergerak di bidang pasokan beras. Pabrik Beras Rosita perlu berjuang sekuat tenaga menggunakan segala kekuatan dan peluang yang ada untuk melakukan strategi pengembangan pasar produk. Pabrik Beras Rosita menyiasati persaingan yang saat ini telah terjadi. Dari uraian diatas dapat dirumuskan permasalahannya adalah Pabrik Beras Rosita belum memiliki rumusan strategi yang akan digunakan dalam menjalankan organisasi guna mencapai tujuan perusahaan Pabrik Beras Rosita sebagai perusahaan bidang pasokan beras dengan memilih bahan baku yang berkualitas dengan memberikan perhatian pada atribut-atribut seperti mempertahankan kepulenan, meningkatkan daya tahan, bentuk atau tekstur serta bau yang menjadi ciri khas kualitas merek yang melekat pada Beras Rosita yang dihasilkan oleh Pabrik Beras Rosita serta harga yang bersaing. Berdasarkan perumusan masalah diatas, dapat diidentifikasi tujuan dalam penelitian ini adalah untuk menganalisis posisi perusahaan Pabrik Beras Rosita melalui analisis Swot yang dimiliki oleh perusahaan serta untuk menganalisis alternatif strategi apa yang sebaiknya diterapkan perusahaan Pabrik Beras Rosita dalam menghadapi persaingan bisnis. 


\section{Journal Competency of Business \\ 2019 Vol 3. No II}

\section{KAJIAN PUSTAKA}

\section{Analisis SWOT}

Menurut David (2007), matriks SWOT merupakan perangkat pencocokan yang penting untuk membantu manajer mengembangkan empat tipe strategi yaitu strategi S (Strength-Opportunity), strategi WO (Weakness-Opportunity), strategi ST (Strenght-Threat) dan stratei WT (Weakness-Threat). Mencocokkan faktor-faktor eksternal dan internal kunci merupakan bagian yang sangta sulit dalam mengembangkan matriks SWOT dan memerlukan penilain baik dan tidak ada sekumpulan kecocokan yang paling baik (David, 2007). Strategi SO atau strategi kekuatan peluang menggunakan kekuatan internal perusahaan untuk memanfaatkan peluang eksternal. Jika perusahaan memiliki kelemahan besar perusahaan akan berusaha keras untuk mengatasi dan membuatnya menjadi kekuatan. Jika menghadapi ancaman besar, sebuah organisasi akan berusaha menghindarinya agar dapat memusatkan perhatian pada peluang.

Strategi WO atau strategi kelemahan-peluang bertujuan memperbaiki kelemahan dengan memanfaatkan peluang eksternal. Strategi ini banyak digunakan untuk menghadapi situasi dimana terdapat banyak peluang eksternal namun juga kelemahan yang ada pada perusahaan membuat perusahaan tidak mampu memanfaatkan peluang tersebut.

\section{METODE PENELITIAN}

\section{Definisi Variabel Operasional}

\section{Variable Internal}

Indikator Variable Internal:

1. Pangsa Pasar

Pangsa pasar adalah seberapa besar daerah pasar yang dapat dikuasai oleh perusahaan untuk memasarkan produknya secara kontinyu.

2. Kualitas Produk 


\section{Journal Competency of Business \\ 2019 Vol 3. No II}

Kwalitas produk adalah kinerja (performance) seperti kehandalan, desain, warna dari produk yang dihasilkan perusahaan.

3. Promosi

Promosi adalah kegiatan untuk mengenalkan perusahaan dan produknya kepada konsumen potensial, melalui iklan, promosi penjualan, personal selling, dan lain-lain.

4. Lokasi Perusahaan.

Lokasi perusahaan adalah tempat dimana perusahaan melakukan aktivitas produksi dan penjualan.

5. Kebijakan harga.

Adalah penentuan besarnya harga yang disesuaikan dengan kualitas produk, untuk menghasilkan harga yang kompetitif dengan harga yang ditetapkan oleh pesaing.

6. Aspek Keuangan.

Aspek keuangan adalah kemampuan keuangan yang dimiliki perusahaan untuk menjalankan aktivitasnya.

7. Sumber Daya Manusia.

Sumber Daya Manusia berhubungan dengan keadaan dan kinerja karyawan yang dimiliki oleh perusahaan untuk menjalankan aktivitasnya.

Tahap kerja matriks IFE:

Membuat daftar critical success factors (faktor-faktor utama yang mempunyai dampak penting pada kesuksesan atau kegagalan dalam pemasaran) untuk aspek internal yang mencakup perihal kekuatan (strengths) dan kelemahan (weaknesses) bagi perusahaan.

a. Menentukan bobot (weight) dari critical success factors tadi dengan skala yang lebih tinggi bagi yang berprestasi tinggi dan begitu pula sebaliknya. Jumlah seluruh bobot harus 1.0. Nilai bobot dicari dan dihitung berdasarkan rata-rata industrinya. 


\section{Journal Competency of Business \\ 2019 Vol 3. No II}

b. Menentukan rating setiap critical success factor antara 1 sampai 4, dimana $1=$ sangat lemah, 2 = tidak begitu lemah, 3 = cukup kuat, 4 = sangat kuat. Jadi rating mengacu kepada kondisi perusahaan, sedangkan bobot mengacu pada industri dimana perusahaan berada.

c. Kalikan antara bobot dan rating dari masing-masing faktor untuk menentukan nilai skornya.

d. Menjumlahkan semua skor untuk mendapatkan skor total bagi perusahaan yang dinilai. Nilai rata-rata adalah 2,5. Jika nilainya dibawah 2,5 menandakan bahwa secara internal perusahaan lemah, sedangkan nilai diatas 2,5 menunjukan posisi internal kuat.

\section{Variable Eksternal}

Indikator variable eksternal:

1. Daya beli konsumen.

Daya beli konsumen merupakan kekuatan/ kondisi uang dimiliki seseorang dalam membelanjakan barang untuk produk-produk .

2. Pertumbuhan pasar.

Yaitu kondisi pasar yang ada saat ini.

3. Perubahan selera konsumen.

Yaitu merupakan perubahan yang terjadi pada keinginan konsumen tentang produk lokal sesuai dengan perkembangan zaman. Beras antara lain beras biasa, beras organik maupun beras analog.

4. Struktur persaingan.

Yakni merupakan kompetensi persaingan pasar antara usaha yang ada selama ini, dalam memperoleh konsumen yang sebesar-besarnya.

5. Pesaing baru yang masuk.

Yakni merupakan perusahaan baru yang bergerak dibidang yang sama, dan mejadi ancaman bagi perusahaan.

6. Kondisi ekonomi makro.

Yakni kondisi ekonomi yang ada didalam negara dan berpengaruh secara luas terhadap kehidupan ekonomi masyarakat, dalam ha ini kemungkinan adanya kegagalan perusahaan sehingga perusahaan beras berkurang.

Tahap kerja matriks EFE: 


\section{Journal Competency of Business \\ 2019 Vol 3. No II}

a. Membuat daftar critical success factors (faktor-faktor utama yang mempunyai dampak penting pada kesuksesan atau kegagalan dalam pemasaran). Aspek eksternal mencakup perihal opportunities (peluang) dan threats (ancaman) bagi perusahaan.

b. Menentukan bobot (weight) dari critical success factor tadi dengan skala yang lebih tinggi bagi yang berprestasi tinggi dan begitu pula sebaliknya. Jumlah seluruh bobot harus 1,0. Nilai bobot dicari dan dihitung berdasarkan rata-rata industrinya.

c. Menentukan rating setiap critical success factor antara 1 sampai 4 , dimana $1=$ dibawah rata-rata, $2=$ rata-rata, $3=$ diatas rata-rata, $4=$ sangat bagus. Rating ditentukan berdassarkan efektivitas strategi perusahaan dengan demikian, nilainya berdasarkan kondisi perusahaan.

d. Nilai bobot dikalikan dengan nilai ratingnya untuk mendapatkan skor semua critical success factor.

e. Jumlahlah semua skor total bagi perusahaan yang dinilai. Skor total 4,0 mengindikasikan bahwa perusahaan merespon dengan cara yang luar biasa terhadap peluang-peluang yang ada dan menghindari ancaman-ancaman di pasar industrinya. Sementara, skor total sebesar 1,0 menunjukan bahwa perusahaan tidak memanfaatkan peluang-peluang yang ada atau tidak menghindari ancaman-ancaman eksternal.

\section{ANALISIS DATA DAN PEMBAHASAN}

\section{Analisis Lingkungan Eksternal}

\section{Matrik Evaluasi Faktor Eksternal (Matrik EFE)}

Dalam penyusunan matrik Evaluasi Faktor Eksternal (Matrik EFE), perlu diketahui dan disusun terlebih dahulu faktor-faktor strategis eksternal yang berpengaruh dalam industri pasokan beras di Jawa Timur. Faktor strategis eksternal terdiri dari faktor-faktor yang menjadi peluang dan faktor-faktor yang menjadi ancaman.Hasil evaluasi penilaian bobot dan peringkat yang dilakuan pada matriks EFE pada perusahaan Pabrik Beras Rosita disusun seperti pada tabel 1 berikut :

\section{Tabel 1 Matriks EFE perusahaan Pabrik Beras Rosita}

\begin{tabular}{|l|l|l|l|}
\hline Faktor-Fator Eksternal Kunci & Bobot & Peringkat & $\begin{array}{l}\text { Nilai yang } \\
\text { dibobot }\end{array}$ \\
\hline Faktor Peluang (Opportunity) & & & \\
\hline 1. Lingkungan Persaingan & 0.13 & 4 & 0.52
\end{tabular}




\section{Journal Competency of Business \\ 2019 Vol 3. No II}

\begin{tabular}{|l|l|l|l|} 
2. Pertumbuhan Industri & 0.12 & 4 & 0.48 \\
3. Ketersediaan Sumber Bahan Baku & 0.10 & 2 & 0.20 \\
4. Mitra Kerja & 0.10 & 3 & 0.30 \\
5. Jumlah Pesaing & 0.11 & 3 & 0.33 \\
6. Kemajuan Teknologi Peralatan & 0.10 & 1 & 0.10 \\
\hline Faktor ancaman (Threat) & & & \\
\hline 1. Kondisi Perekonomian & 0.07 & 1 & 0.07 \\
2. Fluktuasi Nilai Rupiah & 0.05 & 2 & 0.10 \\
3. Kebijakan Pemerintah & 0.06 & 1 & 0.06 \\
4. Stabilitas Politik & 0.07 & 3 & 0.21 \\
5. Inflasi & 0.04 & 4 & 0.16 \\
6. Perubahan Selera Konsumen & 0.05 & 3 & 0.15 \\
\hline
\end{tabular}

Sumber : Data primer diolah

Dari tabel 1 matriks evaluasi faktor eksternal diatas diperoleh hasil nilai yang dibobot sebesar 2.68 atau termasuk di atas nilai rata-rata adalah diatas nilai 2.5. Hal ini berarti dalam usahanya menjalankan strategi secara efektif untuk memanfaatkan peluang ekstenal serta menghindari ancaman eksternal. Menurut David (2007) pada matrik EFE yang telah selesai disusun dengan benar, jika jumlah skor total nilai tertimbang sama dengan 4,0 menunjukkan bahwa organisasi atau perusahaan tersebut telah memanfaatkan peluang-peluang yang ada secaara efektif dan sebaliknya telah meminimalkan segala potensi negatif dari ancaman eksternal.

\section{Analisis Lingkungan Internal dengan Matrik IFE}

Dalam melakukan analisis internal terlebih dahulu identifikasi faktor-faktor strategis internal yang berpengaruh dalam industri Pabrik Beras Rosita. Faktor internal perusahaan merupakan salah satu faktor yang sangat penting dan mempunyai pengaruh terhadap keberhasilan kesuksesan perusahaan Pabrik Beras Rosita. Pengaruh faktor internal terhadap kesuksesan tersebut didominasi oleh faktor manajemen, peralatan, sumber daya manusia, budaya perusahaan dan keuangan. Faktor-faktor yang telah berhasil disusun kemudian dimasukkan kedalam matrik IFE untuk kemudian diberi penilaian seperti dalam Tabel 2 berikut :

Tabel 2 Matriks IFE perusahaan Pabrik Beras Rosita 


\section{Journal Competency of Business \\ 2019 Vol 3. No II}

\begin{tabular}{|c|c|c|c|}
\hline Faktor-Fator Internal Kunci & Bobot & Peringkat & $\begin{array}{l}\text { Nilai } \\
\text { yang } \\
\text { dibobot }\end{array}$ \\
\hline \multicolumn{4}{|l|}{ Faktor Kekuatan (Strength) } \\
\hline 1.Kualitas Produk & 0.11 & 4 & 0.44 \\
\hline $\begin{array}{l}\text { 2.Sebagai perusahaan yang memiliki citra dan reputasi } \\
\text { baik }\end{array}$ & 0.10 & 3 & 0.30 \\
\hline 3.Memiliki likuiditas keuangan yang baik & 0.10 & 2 & 0.20 \\
\hline 4.Variasi desain produk yang berkualitas & 0.10 & 4 & 0.40 \\
\hline 5.Harga produk yang bersaing & 0.11 & 4 & 0.44 \\
\hline 6.Memiliki pangsa pasar potensial & 0.10 & 2 & 0.20 \\
\hline Faktor Kelemahan (Weakness) & & & \\
\hline
\end{tabular}

\begin{tabular}{|c|c|c|c|}
\hline Faktor Kelemahan (Weakness) & Bobot & Peringkat & $\begin{array}{l}\text { Nilai } \\
\text { yang } \\
\text { dibobot }\end{array}$ \\
\hline 1.Belum memiliki strategi bersaing yang jelas & 0.07 & 2 & 0.14 \\
\hline 2.Keterbatasan kompetensi pekerja & 0.07 & 1 & 0.07 \\
\hline 3.Pengendalian produksi kurang terintegrasi & 0.05 & 3 & 0.15 \\
\hline $\begin{array}{l}\text { 4.Keterbatasan kompetensi manajemen dalam } \\
\text { menginternalisasi visi dan misi perusahaan }\end{array}$ & 0.07 & 2 & 0.14 \\
\hline 5.Kekurangan SDM dibagian produksi & 0.07 & 1 & 0.07 \\
\hline \multirow{2}{*}{$\begin{array}{l}\text { 6. Pencatatan laporan keuangan yang tidak dilakukan } \\
\text { secara periodik }\end{array}$} & 0.05 & 3 & 0.15 \\
\hline & 1.00 & & 2.70 \\
\hline & & & \\
\hline
\end{tabular}

Sumber : Data primer diolah 


\section{Journal Competency of Business \\ 2019 Vol 3. No II}

Dari tabel 1 matrik evaluasi faktor internal diatas diperoleh hasil nilai 2.70 atau termasuk dalam kategori di atas nilai rata-rata adalah diatas nilai 2.5 sehingga dapat disimpulkan bahwa Pabrik Beras Rosita menjalankan strategi secara efektif untuk memanfaatkan kekuatan internal serta meminimalkan kelemahan internal.

\section{Matrik SWOT (Strenght-Weakness-Opportunities-Threats)}

Setelah mengumpulkan semua informasi yang bepengaruh terhadap kelangsungan perusahaan, tahap selanjutnya adalah memanfaatkan semua informasi dalam model-model perumusan strategi. Dalam hal ini menggunakan model Matrik SWOT. Menurut David (2007) Strategi S-O atau strategi kekuatanpeluang menggunakan kekuatan internal perusahaan untuk memanfaatkan peluang eksternal, strategi W$\mathrm{O}$ atau strategi kelemahan-peluang bertujuan untuk memperbaiki kelemahan dengan memanfaatkan peluang eksternal, strategi S-T atau strategi kekuatan ancaman menggunakan kekuatan untuk menghindari atau mengurangi dampak dari ancaman eksternal dan strategi W-T atau strategi kelemahan ancaman merupakan taktif defensif yang diarahkan untuk mengurangi kelemahan internal dan menghindari ancaman eksternal. Langkah-langkah dalan nelakukan analisis SWOT dilakukan sebagai berikut :

\section{Penyusunan alternatif strategi S-O (strategi kekuatan - peluang)}

Penyusunan alternatif strategi S-O bedasarkan semua faktor-faktor utama dari faktor kekuatan dan faktor peluang. Dari faktor-faktor tersebut diatas selanjutnya diperoleh alternatif strategi S-O sebagai berikut :

a. Meningkatkan penetrasi pasar potensial dengan lebih agresif, tidak hanya beroperasi secara lokal

b. Meningkatkan networking (jaringan) dengan mitra kerja strategis secara berkesinambungan

c. Meningkatkan kinerja dan mutu untuk mempertahankan reputasi

d. Mengupayakan perolehan hasil produksi yang mempunyai nilai strategis dan high technology

e. Meningkatkan efisiensi demi tercapai cost leadership tanpa mengesampingkan kualitas produk

f. Dengan dana yang tersedia, melakukan riset untuk menciptakan produk andalan yang menjadi ciri khas Pabrik Beras Rosita 


\section{Journal Competency of Business \\ 2019 Vol 3. No II}

\section{Penyusunan alternatif strategi W-O (Strategi Kelemahan-Peluang)}

Penyusunan alternatif strategi W-O berdasarkan semua faktor utama dari faktor kelemahan internal organisai dan faktor-faktor peluang organisasi. Dari faktor-faktor tersebut diatas selanjutnya diperoleh alternatif strategi W-O sebagai berikut :

a. Segera menyusun strategi organisasi yang komprehensif

b. Pengoptimalan sistem keuangan dan kontrol secara kontinyu

c. Membangun sistem pelatihan karyawan yang baik

d. Monitoring penerapan sistem pengendalian manajemen Pabrik Beras Rosita

e. Memberdayakan anggota organisasi untuk merealisasikan visi dan misi perusahaan

f. Mencari info dini untuk sasaran kelulusan tenaga kerja yang unggul di bidang produksi

\section{Penyusunan Alternative Strategi S-T (Strategi Kekuatan-Ancaman)}

Penyusunan alternaif strategi S-T berdasarkan semua faktor utama dari faktor kekuatan internal organisasi dan faktor-faktor ancaman eksternal organisasi. Dari faktor-faktor tersebut diatas selanjutnya diperoleh alternatif strategi S-T sebagai berikut :

a. Meningkatkan kemampuan manajemen risiko

b. Meningkatkan kekuatan keuangan (financial strength)

c. Meningkatkan riset pasar secara kontinyu untuk mengantisipasi perubahan selera konsumen.

d. Mengikuti perkembangan regulasi yang dikeluarkan pemerintah.

e. Mengembangkan SDM yang ahli multi solusi sehingga meningkatkan economies of quantity.

\section{Penyusunan alternatif strategi W-T (Strategi kelemahan - ancaman)}

Penyusunan alternatif strategi W-T berdasarkan faktor-faktor utama dari faktor kelemahan internal dan faktor-faktor ancaman eksternal organisasi. Alternatif strategi ini pada prinsipnya adalah strategi defensif yang diarahkan untuk mengurangi kelemahan internal dan menghindari ancaman eksternal. Faktor-faktor utama yang menjadi kelemahan dan ancaman organisasi yang menjadi landasan strategi W-T adalah sebagai berikut:

a. Segera menyusun strategi organisasi yang efektif.

b. Benchmarking dan studi banding terhadap pesaing baru.

c. Menerapkan sistem manajemen secara menyeluruh untuk pengendalian produksi.

d. Outsourching personel ahli di bidang produksi. 


\section{Journal Competency of Business \\ 2019 Vol 3. No II}

e. Menciptakan visi misi yang terarah.

f. Peningkatan mutu Sumber Daya Manusia di perusahaan.

Hasil analisis SWOT yang telah dilakukan kemudian disusun kedalam sebuah matriks seperti ditunjukkan pada tabel 3 berikut :

Tabel 3 Matriks SWOT perusahaan Pabrik Beras Rosita

\begin{tabular}{|c|c|c|}
\hline & $\begin{array}{l}\text { Kekuatan-S } \\
\text { 1.Kualitas Produk } \\
\text { 2.Sebagai perusahaan yang memiliki citra } \\
\text { dan reputasi baik } \\
\text { 3.Memiliki likuiditas keuangan yang baik } \\
\text { 4.Variasi desain produk yang berkualitas } \\
\text { 5.Harga produk yang bersaing } \\
\text { 6.Memiliki pangsa pasar potensial }\end{array}$ & $\begin{array}{l}\text { Kelemahan-W } \\
\text { 1.Belum memiliki strategi bersaing } \\
\text { yang jelas } \\
\text { 2.Keterbatasan kompetensi pekerja } \\
\text { 3.Pengendalian produksi kurang } \\
\text { terintegrasi kompetensi } \\
\begin{array}{l}\text { 4.Keterbatasan dibagian } \\
\text { manajemen dalam menginternalisasi } \\
\text { visi dan misi perusahaan }\end{array} \\
\text { 5.Kekurangan SDM } \\
\text { produksi } \\
\text { 6. Pencatatan laporan keuangan yang } \\
\text { tidak dilakukan secara periodik }\end{array}$ \\
\hline $\begin{array}{l}\text { Peluang -0 } \\
\text { 1.Lingkungan } \\
\text { Persaingan }\end{array}$ & $\begin{array}{l}\text { Strategi S-O } \\
\text { a. Meningkatkan penetrasi pasar potensial } \\
\text { dengan lebih agresif, tidak hanya } \\
\text { beroperasi secara lokal } \\
\text { b.Meningkatkan networking (jaringan) } \\
\text { dengan mitra kerja strategis secara } \\
\text { berkesinambungan }\end{array}$ & $\begin{array}{l}\text { Strategi W-O } \\
\text { a. Segera menyusun strategi } \\
\text { organisasi yang komprehensif } \\
\text { b. Pengoptimalan sistem keuangan } \\
\quad \text { dan kontrol secara kontinyu }\end{array}$ \\
\hline $\begin{array}{l}\text { 3. Ketersediaan } \\
\text { Sumber Bahan } \\
\text { Baku }\end{array}$ & $\begin{array}{l}\text { c. Meningkatkan kinerja dan mutu untuk } \\
\text { mempertahankan reputasi } \\
\text { d. Mengupayakan perolehan hasil } \\
\text { produksi yang mempunyai nilai strategis } \\
\text { dan high technology }\end{array}$ & $\begin{array}{l}\text { c. Membangun sistem pelatihan } \\
\text { karyawan yang baik } \\
\text { d. Monitoring penerapan sistem } \\
\text { pengendalian manajemen } \\
\text { Pabrik Beras Rosita }\end{array}$ \\
\hline 5 Jumlah Pesaing & $\begin{array}{l}\text { e. Meningkatkan efisiensi demi tercapai } \\
\text { cost leadership tanpa mengesampingkan } \\
\text { kualitas produk }\end{array}$ & $\begin{array}{l}\text { e. Memberdayakan anggota } \\
\text { organisasi untuk } \\
\text { merealisasikan visi dan misi } \\
\text { perusahaan }\end{array}$ \\
\hline
\end{tabular}




\section{Journal Competency of Business \\ 2019 Vol 3. No II}

\begin{tabular}{|c|c|c|}
\hline $\begin{array}{l}\text { 6.Kemajuan } \\
\text { Teknologi } \\
\text { Peralatan }\end{array}$ & $\begin{array}{l}\text { f. Dengan dana yang tersedia, melakukan } \\
\text { riset untuk menciptakan produk andalan } \\
\text { yang menjadi ciri khas Pabrik Beras } \\
\text { Rosita }\end{array}$ & $\begin{array}{l}\text { f. Mencari info dini untuk sasaran } \\
\text { kelulusan tenaga kerja yang } \\
\text { unggul di bidang produksi }\end{array}$ \\
\hline Ancaman-T & Strategi S-T & Strategi W-T \\
\hline $\begin{array}{l}\text { 1.Kondisi } \\
\text { Perekonomian }\end{array}$ & $\begin{array}{l}\text { a. Meningkatkan kemampuan manajemen } \\
\text { risiko }\end{array}$ & $\begin{array}{l}\text { Segera menyusun strategi } \\
\text { organisasi yang efektif }\end{array}$ \\
\hline $\begin{array}{l}\text { 2.Fluktuasi Nilai } \\
\text { Rupiah }\end{array}$ & $\begin{array}{l}\text { b. Meningkatkan kekuatan keuangan } \\
\text { (financial strength) }\end{array}$ & $\begin{array}{l}\text { b. Benchmarking dan studi banding } \\
\text { terhadap pesaing baru }\end{array}$ \\
\hline $\begin{array}{l}\text { 3.Kebijakan } \\
\text { Pemerintah }\end{array}$ & $\begin{array}{l}\text { c. Meningkatkan riset pasar secara } \\
\text { kontinyu untuk mengantisipasi } \\
\text { perubahan selera konsumen }\end{array}$ & $\begin{array}{l}\text { c. Menerapkan sistem manajemen } \\
\text { secara menyeluruh untuk } \\
\text { pengendalian produksi }\end{array}$ \\
\hline $\begin{array}{l}\text { 4. Stabilitas } \\
\text { Politik }\end{array}$ & $\begin{array}{l}\text { d. Mengikuti perkembangan regulasi yang } \\
\text { dikeluarkan pemerintah }\end{array}$ & $\begin{array}{l}\text { d. Outsourching personel ahli di } \\
\text { bidang produksi }\end{array}$ \\
\hline 5. Inflasi & $\begin{array}{l}\text { e. Mengembangkan SDM yang ahli multi } \\
\text { solusi sehingga meningkatkan } \\
\text { economies of quantity }\end{array}$ & e. Menciptakan visi misi yang terarah \\
\hline $\begin{array}{lr}6 . & \text { Perubahan } \\
\text { Selera } & \text { Konsumen }\end{array}$ & & $\begin{array}{l}\text { f. Peningkatan mutu Sumber Daya } \\
\text { Manusia di perusahaan }\end{array}$ \\
\hline
\end{tabular}

Sumber : Data primer diolah

Apabila Pabrik Beras Rosita berada dalam posisi yang baik sekali untuk menggunakan kekuatan internalnya untuk memanfaatkan peluang eksternal, mengatasi kelemahan internal serta menghindari ancaman eksternal maka terdapat beberapa alternativ pilihan strategi yang harus diterapkan yaitu antara lain strategi intensif (penetrasi pasar, pengembangan pasar, dan pengembangan produk). Keputusan yang tepat dalam strategi pertumbuhan akan berpengaruh terhadap keseluruhan langkah yang ada, sehingga perbedaan antar kategori yang ada harus dapat dengan jelas teridentifikasi. Ada 4 kategori dalam strategi konsentrasi pertumbuhan perusahaan. Dengan pemililahan kategori konsentrasi strategi pertumbuhan perusahaan jadi lebih tahu dan menguasai apa yang dilakukannya. dengan memilih salah satu kategori yang ada dalam 4 kategori konsentrasi maka manajer strategi telah mengenal dengan baik tentang industri, pelanggan, dan para pesaingnya. Semua yang ada dalam organisasi perusahaan dapat mengonsentrasikan diri pada bisnis yang intinya, mengembangkannya, dan mengekploitasi sumber daya utama, kapabilitas, dan kompetensi inti yang dimilikinya agar dapat sukses dipasar. 


\section{Journal Competency of Business 2019 Vol 3. No II}

Hasil wawancara dengan owner Pabrik Beras Rosita, bahwa pihak perusahaan telah melakukan pengembangan pasar dengan upaya memperkenalkan produk Pabrik Beras Rosita ke wilayah luar Kediri dan luar Jawa Timur. Pihak perusahaan menyadari bahwa permintaan beras oleh di luar wilayah Kediri dan luar Jawa Timur sangat tinggi yang menginginkan keberadaan produk Pabrik Beras Rosita di kota lainnya untuk memenuhi kebutuhan pangan.

Seperti kita ketahui, daerah Jawa Timur dikenal sebagai daerah penghasil pertanian yang besar, contohnya produksi beras di Kediri, Jawa Timur. Hal ini bisa dilihat dari banyaknya pabrik-pabrik beras yang ada di daerah Kediri yang tentunya pabrik-pabrik tersebut harus dapat bersaing untuk memperebutkan pangsa pasar di wilayah Jawa Timur secara khusus. Salah satu pabrik beras di Jawa Timur adalah Pabrik Beras Rosita. Pabrik Beras Rosita merupakan salah satu perusahaan yang ada di daerah Kediri yang bergerak di bidang pasokan beras. Seperti kita ketahui beras merupakan makanan pokok yang tidak dapat dipisahkan dari kehidupan manusia khususnya masyrakat di Indonesia. Bahkan ada istilah bahwa "belum makan jika belum makan nasi". Atas dasar itu maka usaha pabrik beras harus dapat tetap menjaga eksistensinya sebab permintaan akan makanan pokok beras tidak akan pernah habis. 


\section{Journal Competency of Business \\ 2019 Vol 3. No II}

\section{Simpulan, Implikasi, Saran, Keterbatasan}

Berdasarkan hasil analisis yang dilakukan dengan mengunakan model 5 kekuatan Michael Porter menunjukkan bahwa industri pasokan beras di Kediri masih menarik. Hal ini ditandai dengan nilai daya tarik berdasarkan analisis persaingan dalam industri dalam kategori tinggi, perusahaan Pabrik Beras Rosita sampai harus terus-menerus melakukan kompetisi untuk mendapatkan posisi pasar dengan upayaupaya mengutamakan persaingan kualitas, produk serta harga untuk meningkatkan pelayanan atau jaminan kepuasan. Mengingat daerah Jawa Timur dikenal sebagai daerah penghasil pertanian yang besar. Peluang yang besar dalam memperoleh keuntungan tersebut harus disikapi oleh pelaku bisnis dengan perumusan dan menerapkan strategi yang handal dalam upaya memenangkan persaingan.

Dari hasil serangkaian analisis dalam penyusunan strategi pada Pabrik Beras Rosita diperoleh kesimpulan bahwa pilihan strategi pengembangan pasar sebagai salah satu alternatif strategi yang terbaik yang dapat diterapkan oleh Pabrik Beras Rosita dalam menghadapi persaingan bisnis. Terbukit dari hasil wawancara dengan owner Pabrik Beras Rosita, bahwa pihak perusahaan telah melakukan pengembangan pasar dengan upaya memperkenalkan produk Pabrik Beras Rosita ke wilayah luar Kediri dan luar Jawa Timur. Pihak perusahaan menyadari bahwa permintaan beras oleh di luar wilayah Kediri dan luar Jawa Timur sangat tinggi yang menginginkan keberadaan produk Pabrik Beras Rosita di kota lainnya untuk memenuhi kebutuhan pangan.

Saran yang bisa diberikan Pabrik Beras Rosita agar mampu berdaya saing untuk mencapai keunggulan kompetitif adalah:

1. Berdasarkan pengamatan yang dilakukan, Pabrik Beras Rosita memiliki kelemahan keterbatasan kompetensi manajemen dalam menginternalisasi visi dan misi perusahaan maka Pabrik Beras Rosita harus segera mengelola dengan baik sistem manajemen secara lebih professional serta harus segera memetakan visi misi perusahaan sehingga Pabrik Beras Rosita akan mempunyai kompetensi manajemen dalam menginternalisasi visi dan misi perusahaan secara professional. Pabrik Beras Rosita juga perlu melakukan pengoptimalan sistem keuangan dan kontrol secara kontinyu sehingga akan memudahkan dalam menentukan strategi yang akan diterapkan.

2. Pabrik Beras Rosita harus lebih agresif dalam memanfaatkan peluang yang ada, serta disertai dengan segera menentukan strategi yang akan diterapkan dalam menjalan organisasi untuk mencapai tujuan organisasi. Faktor-faktor yang menjadi titik lemah harus diatasi melalui peningkatan jaringan berupa 


\section{Journal Competency of Business \\ 2019 Vol 3. No II}

kerjasama dengan pemasok dan mitra kerja, meningkatkan kemampuan manajemen risiko dan mencari tenaga kerja SDM di bidang produksi yang memiliki kompetensi.

Pihak perusahaan menyadari bahwa permintaan beras di luar wilayah Jawa Timur sangat tinggi. Untuk kedepannya, sebaiknya Pabrik Beras Rosita terus melakukan pengembangan pasar untuk memperkenalkan produk ke wilayah potensial lainnya seperti di wilayah Indonesia bagian timur. Sehingga khususnya bagi Pabrik Beras Rosita harus mampu bersaing dan selalu memberikan nilai tambah kepada konsumen untuk mendapatkan peluang. 


\section{Journal Competency of Business \\ 2019 Vol 3. No II}

\section{DAFTAR PUSTAKA}

David, R. Fread,. 2007. Manajemen Strategi, Edisi 12. Jakarta : Salemba Empat.

Dedi, Kusmayadi. 2008. Pengaruh Lingkungan Bisnis Terhadap Perusahaan: Sebuah Tinjauan Teoritis dan Empiris. Jurnal Akuntansi FE Unsil. Vol. 3. No. 2

Dewi, Aulia dan Andri Ikhwana. 2010. Perencanaan Strategi Pengembangan Usaha Kain Tenun Sutra Dengan Pendekatan Metode Balance Scorecard (Studi Kasus di Pabrik Sutera TigaPutra). Jurnal Kalibrasi Sekolah Tinggi Teknologi Garut. Vol 5 No 2

Friska, Sipayung. 2009. Balance Scorecard: Pengukuran Kinerja Perusahaan dan Sistem Manajemen Strategis. Jurnal Manajemen Bisnis, Vol 2. No 1

Hitt, Michael A and Irealand R.D,. 2001 . Manajemen Strategis Daya Saing dan Globalisasi, Konsep Buku I. Jakarta : Salemba Empat.

Hunger J. D. dan Thomas L.W. 2001. Manajemen Strategis, Edisi Indonesia, Yogyakarta : Andi Offset

Husein, Umar. 2003. Strategi Manajemen In Action, Edisi 3. Jakarta : Gramedia Pustaka Indonesia

Kotler, Philip. 2003. Marketing Management, $11^{\text {th }}$ Edition, New Jersey : Prentice Hall . 2005 Manajemen Pemasaran. Jilid 1. Jakarta : Gramedia Pustaka Utama

Kotler, Philip., dan Garry Amstrong. 1996. Principle of Marketing, $9^{\text {th }}$ ed, New Jersey: Prentice Hall

Kuncoro, Mudrajad. 2006. Strategi Bagaimana Meraih Keunggulan Kompetitif. Yogyakarta: Penerbit Erlangga

Kurniawati dan Sari. 2009. Analisis dan Pilihan Strategi: Membangun Esksistensi Perusahaan di Masa Krisis. Jurnal Ekonomi Bisnis. Vol 14. No 3

Porter, Michael E. 2008. Keunggulan Bersaing: Menciptakan dan Mempertahankan Kinerja Unggul. Jakarta : Binarupa Aksara.

Samputno. 2010. Manajemen Strategik: Menciptakan Keunggulan Bersaing yang Berkelanjutan. Gajah Mada University Press. Yogyakarta

Supartono. 2007. Analisis Faktor-faktor Bauran Pemasaran yang Dipertimbangkan Konsumen Dalam Keputusan Pembelian Ice Cream "Mini Melts" di Kota Surabaya. Jurnal Akuntansi, Manajemen Bisnis dan Sektor Publik (JAMBSP). Vol.3 No. 3

Suwarsono, M. 2002. Manajemen Strategi Tentang Konsep dan Kasus, Edisi pertama. Yogyakarta : UPP AMP YKPN

\section{YKPN}

Tjiptono, F. 2005. Strategi Pemasaran. Yogyakarta : PT Andi Offset 


\section{Journal Competency of Business 2019 Vol 3. No II}

Tri, Handayani. 2013. Pengaruh Lingkungan Makro Terhadap Kinerja Usaha (Studi Pada Usaha Kecil Menengah Makanan Di Kota Pekanbaru). Inovbiz, Vol 1, No 1

Umar, H. 2002. Strategic Management in Action: Konsep, Teori, dan Teknik Menganalisis Manajemen Strategis . Jakarta : PT. Gramedia Pustaka Umum

Widarsono, Agus. 2009. Strategic Value Chain Analysis (Analisis Stratejik Rantai Nilai): Suatu pendekatan Manajemen. Yogyakarta : PT Andi Offset

Wisdaningrum, Oktavima. 2013. Analisis Rantai Nilai (Value Chain) Dalam Ingkungan Internal Perusahaan. Analisa Vol. 1. No 1

Zahara, Nurul. 2014. Strategi Pertumbuhan Bisnis Kerajinan Perak di Kotagede Studi $\quad$ Kasus $\quad$ Pada Kerajinan Perak Dalas (Analisis dengan Pendekatan Matriks SPACE). Thesis Pasca Sarjana Magister Manajemen Universitas Islam Indonesia (Tidak Dipublikasikan) 